\title{
BIG DATA - CATALYST OF SUSTAINABLE DEVELOPMENT
}

\section{Mirela Danubianu ${ }^{1}$}

Keywords: sustainable development, Big Data for Development

\begin{abstract}
Sustainable development involves meeting the needs of the current generation without affecting the possibility of future generations to meet their own needs. This implies the correlation of the immediate objectives with the long-term ones at local and global level, considering the economic and environmental aspects in close interdependence. Released around 2010, Big Data is a generic term that refers those data sets whose features make it impossible to process with traditional database tools. Beyond the significant dimensions, Big Data is defined by the so-called set of Big Data Vs: volume, variety, velocity, veracity, volatility and, not least by the value that their analysis adds to the decision-making process. Starting with 2013, the United Nations through the Global Pulse initiative has defined a new concept - Big Data for Development. It aims to find those data sources whose analysis provides valuable information for ensuring the well-being and development of the society. In 2015, the United Nations launched a new agenda that supports 17 sustainable development goals, whose achievement involves integrated actions that will solve social, economic and environmental problems in a way that will reduce disparities. As we are in the middle of the digital revolution, the following question is inevitable: to what extent and in what way can the data collected and analyzed using the latest technologies help to implement policies that will lead to these objectives? This paper aims to provide a qualitative analysis of how Big Data analytics can influence decisions and catalyze the implementation of policies that will result in achieving sustainable development goals.
\end{abstract}

\section{Sustainable development - Concept, goals and European Union implemantation}

\subsection{The concept of sustainable development and its goals}

The last half century we have witnessed an explosive development in all life areas. The accelerated evolution of the worldwide economies and the increase of the globally birth rate have as effect, among other things, the awareness that planetary resources are limited and there is the possibility of

1 “Ştefan cel Mare” University of Suceava, mdanub@eed.usv.ro 
their breakdown, which would lead to a catastrophe. The deepening of social disparities and the degradation of the environment in all its components have also raised a lot of concerns. Starting from this reality, nowadays the phrase "sustainable development" is very frequently used. In the vision of the World Commission on Environment and Development this is defined as "the development that aims to satisfy the needs of the present generations, without compromising the possibility of future generations to meet their own needs". This involves finding the development paths that ensure a balanced and integrated approach of the social, economic and environmental problems, because they are considered as inseparable components of evolution. Also, the immediate objectives should be incorporated in the medium and long terms ones, and the actions at the local level should be harmonized with those at the global level.

Considering planetary realities, in Brundtland Commission Report written in 1987 and known as "Our Common Future" (Brundtland Report, 1987), three vectors of sustainable development were established, namely: social equity, economic growth and environment (Strategia Națională pentru Dezvoltarea Durabilă a României - 2030).

All these directions were considered by the United Nations which, on September $25^{\text {th }}, 2015$ adopted the Agenda 2030 for Sustainable Development. This establishes 17 general sustainable development goals, monitored through 169 specific themes, measured based on about 230 targets (Agenda for Sustainable Development, 2015).

Depending on the measurement methodology, standards and the availability of data needed for measurement or monitoring, they are divided into three categories. In categories 1 and 2 are those targets whose indicators are clearly conceptualized and for which the methodologies and standards are well established. The difference between the two categories is that for the targets in the first category the data are regularly produced by the countries, while for the second one these data are not regularly produced. The third category refers to those targets for which neither methodologies nor standards have yet been established (The Classification for Global SDG Indicators). Table 1 presents the Agenda 2030 for Sustainable Development goals (SDG), along with several measurable targets associated with each of them. 
TABLE 1 General goals (SDG) and some specific themes in Agenda 2030 for Sustainable Development

\begin{tabular}{|c|c|c|}
\hline $\begin{array}{l}\text { Nr. } \\
\text { Crt. }\end{array}$ & General goal & Specific themes \\
\hline 1 & No Poverty & $\begin{array}{l}\text { - socio-economic status and wellbeing assessment } \\
\text { - poverty mapping } \\
\text { - disaster response }\end{array}$ \\
\hline 2 & Zero Hunger & $\begin{array}{l}\text { - food expenditures tracking } \\
\text { - drought monitoring } \\
\text { - early evaluation of crop yield } \\
\text { - price indexing }\end{array}$ \\
\hline 3 & Good Health and Well-Being & - diseases propagation \\
\hline 4 & Quality Education & $\begin{array}{l}\text { - the illiteracy prediction } \\
\text { - school dropout prediction }\end{array}$ \\
\hline 5 & Gender Equality & - gender prediction \\
\hline 6 & Clean Water and Sanitation & - changes in water-related ecosystems \\
\hline 7 & Affordable and Clean Energy & $\begin{array}{l}\text { - access to electricity } \\
\text { - electricity consumption }\end{array}$ \\
\hline 8 & $\begin{array}{l}\text { Decent Work and Economic } \\
\text { Growth }\end{array}$ & $\begin{array}{l}\text { - GDP level } \\
\text { - unemployment rate } \\
\text { - the scale of tourism }\end{array}$ \\
\hline 9 & $\begin{array}{l}\text { Industry, Innovation and } \\
\text { Infrastructure }\end{array}$ & $\begin{array}{l}\text { - investments in research and development } \\
\text { - monitoring of greenhouse gas emissions } \\
\text { - transport planning }\end{array}$ \\
\hline 10 & Reduced Inequality & $\begin{array}{l}\text { - assessment of socio-economic status and } \\
\text { wellbeing }\end{array}$ \\
\hline 11 & $\begin{array}{l}\text { Sustainable Cities and } \\
\text { Communities }\end{array}$ & $\begin{array}{l}\text { - assessing urban poverty } \\
\text { - mapping poverty } \\
\text { - transport planning } \\
\text { - land use } \\
\text { - disaster response }\end{array}$ \\
\hline 12 & $\begin{array}{l}\text { Responsible Consumption } \\
\text { and Production }\end{array}$ & $\begin{array}{l}\text { - production estimation } \\
\text { - consumption prediction }\end{array}$ \\
\hline 13 & Climate Action & $\begin{array}{l}\text { - changes in water-related ecosystem } \\
\text { - drought monitoring } \\
\text { - disaster response }\end{array}$ \\
\hline 14 & Life Below Water & $\begin{array}{l}\text { - identification of illegal fishing } \\
\text { - identification of the penetration of the vessels in } \\
\text { the protected spaces }\end{array}$ \\
\hline 15 & Life on Land & $\begin{array}{l}\text { - identification of deforestation } \\
\text { - combating desertification } \\
\text { - protection of rare species }\end{array}$ \\
\hline
\end{tabular}




\begin{tabular}{|c|c|c|}
\hline 16 & $\begin{array}{l}\text { Peace, Justice and Strong } \\
\text { Institutions }\end{array}$ & $\begin{array}{l}\text { - prediction of criminal phenomena } \\
\text { - citizens' perception of violence } \\
\text { - tracking the efficiency of justice systems }\end{array}$ \\
\hline 17 & $\begin{array}{l}\text { Partnerships for the Goals } \\
\text { Achievement }\end{array}$ & $\begin{array}{l}\text { - trade relations between advanced and } \\
\text { developing countries } \\
\text { - supporting developing countries to consolidate } \\
\text { resources } \\
\text { - setting up governmental, non-governmental, } \\
\text { non-profit or civil society organizations to } \\
\text { support sustainable development. }\end{array}$ \\
\hline
\end{tabular}

\subsection{The stage of implementation of the sustainable development objectives in the European Union}

Currently, Europe is one of the most suitable living areas on the planet. At global level, according to (Dezvoltarea durabilă în Uniunea Europeană, 2018), seven of the EU-27 member states are ranked among the top 10 in the global sustainable development goals hierarchy and all Member States are in the top 50 of the 156 countries evaluated. However, it is clear that the EU must continue to

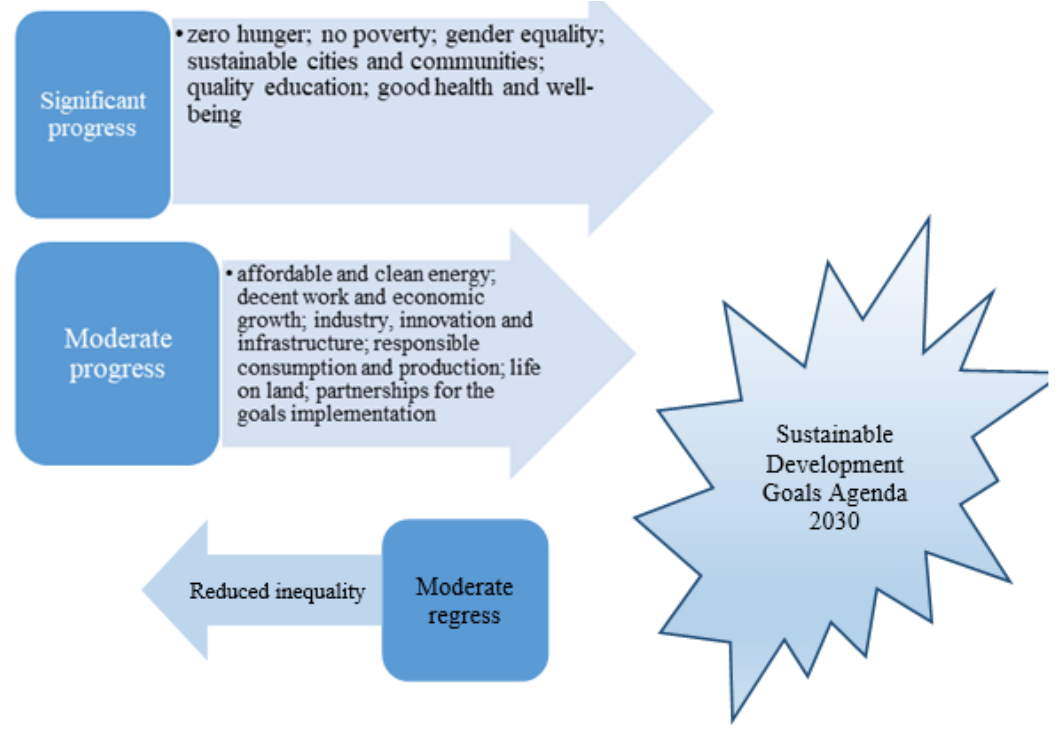

Fig. 1 Trends of SDG implementation at European Union level

work in all directions for sustainable development, because, according to the same document, there are goals for which progress has been made, but at the same time there are goals for which there has been a move away of the 
proposed targets. Fig. 1 shows the trends concerning the implementation of sustainable development goals at the EU level.

\section{Big data - concept and characteristics}

Big Data is a relatively new and constantly evolving concept, and refers to those datasets, whose characteristics exceed the storage and processing possibilities of traditional database systems. Moreover, Big Data implies the existence of some features, known as the "Big Data Vs". The most known are data volume, variety and velocity (Danubianu, Barila, 2014).

Although the word "Big" may suggest as the main attribute of the Big Data concept, a large volume, the size of the data must be evaluated by reference to the context, because there is no minimum imposed limit for a dataset to be included in this category. It is known that some organizations work with gigabytes or terabytes of data, while others, such as social media organizations, collect and manipulate petabytes or exabytes of data. But in both cases, there may be requirements for complex data processing and analysis that are specific to Big Data applications. The critical attribute for Big Data is the variety, generated by data joining from different sources with different formats. Combining this data for further analysis is a big challenge. The velocity is related to the speed with which data is generated and collected, as well as the speed with which they are processed and analyzed, and the resulting information is delivered to the stakeholders. There are organizations for which obtaining real-time information is essential, and a delay of a few seconds can make the difference between a good decision and a bad one. There are other organizations for which the analysis must be done with great precision, without strong restrictions on response times. Therefore, it must be considered that for each case, the correct information must be provided at the right time (Danubianu, Barila, 2014).

Starting from these three Vs and based on the information we can obtain through a correct Big Data analysis, another V- value can be added. It is obvious that these datasets hide valuable information that can be revealed through specific analysis. Big Data analysis allows an organization to better understand the relationship between its evolution and events in the environment. This can lead to better decisions and a stronger competitive position (Danubianu, Barila, 2014).

Big Data analysis is a complex process that consists of several phases: data acquisition and capture, data cleaning, data integration and aggregation, as stages of preparing a dataset for extracting information, modeling and finally results visualization. In addition, Big Data analytics refer strategies aimed to 
target the discovery of models and associations that would otherwise be invisible. These allow organizations to leverage their data and to use it to identify new opportunities by providing valuable information to users.

Big Data analytics can take many forms:

- descriptive analytics - combine raw data from multiple sources to consolidate information about the past without explaining the reason for the occurrence of different events or phenomena;

- diagnostic analytics - explain, based on historical data the reason or context in which the different events take place, finding dependencies and identifying patterns;

- prescriptive analytics - focus on the models that seek to solve specific problems and indicate the actions that should be performed. The results are reflected in rules and recommendations for the future;

- predictive analytics - starting from the descriptive and diagnostic analyzes show what can happen. Their purpose is to detect trends, groups and exceptions and to predict future behaviors. They are valuable tools for forecasting (Paraschiv, Danubianu, 2019).

The four types of analytics must be combined for a complete view on a topic. Essential tools for data analysis are visualization, statistics, detection of associations, and machine learning methods such as classification and clustering.

\section{Big data and sustainable development}

\subsection{Big Data for Development (BD4D)}

Undoubtedly, we live in a complex, hyper-connected and volatile world, where we frequently face vulnerabilities and risks, and the watchword has become - agility. In this context Big Data analyzes can ensure agile and sustainable development policies.

In 2012, the Global Pulse Group (Big Data for Development, 2012), a United Nations initiative that functions as a hub for applying data science innovations to global development and solving humanitarian challenges, proposes a distinct dimension for Big Data, namely: Big Data for Development (BD4D).

The Big Data for Development concept aims to identify those sources whose analysis provides valuable information for ensuring the well-being and development of the society and which are relevant to the policies and planning of the development programs. This is distinguished from the traditional idea of 
Table 2. Big Data sources and applications for sustainable development

\begin{tabular}{|c|c|c|}
\hline Target theme & Big Data sources & $\begin{array}{c}\text { Applications supporting sustainable } \\
\text { development }\end{array}$ \\
\hline \multicolumn{3}{|c|}{ 1. No Poverty } \\
\hline $\begin{array}{c}\text { - socio-economic } \\
\text { status and wellbeing } \\
\text { assessment } \\
\text { - poverty mapping } \\
\text { - disaster response }\end{array}$ & $\begin{array}{l}\text { - mobile phone } \\
\text { data } \\
\text { - satellites data }\end{array}$ & $\begin{array}{l}\text { - the mobile services expenses pattern is } \\
\text { an indicator of the standard of living; } \\
\text { - the analysis of telephone calls records } \\
\text { details allows the identification of } \\
\text { people mobility after disasters; } \\
\text { - the analysis of satellites data leads to } \\
\text { poverty mapping; }\end{array}$ \\
\hline \multicolumn{3}{|c|}{ 2. Zero Hunger } \\
\hline $\begin{array}{l}\text { - expenditures on food } \\
\text { tracking; } \\
\text { - food prices } \\
\text { monitoring; } \\
\text { - drought monitoring } \\
\text { and early crop yield } \\
\text { assessment; }\end{array}$ & $\begin{array}{c}\text { - online prices; } \\
\text { - mobile phone } \\
\text { data; } \\
\text { - satellites data } \\
\text { - various surveys } \\
\text { data; } \\
\text { - social media data }\end{array}$ & $\begin{array}{l}\text { - the analysis of the mobile phone } \\
\text { activity, airtime credit and several food } \\
\text { items purchase reveal a strong } \\
\text { correlation; } \\
\text {-tracking the food-related posts on socia } \\
\text { media could reveal, in an early stage, } \\
\text { food inflation; } \\
\text { - the drought detection and } \\
\text { quantification is possible by analyzing } \\
\text { data provided by meteorological } \\
\text { satellites; } \\
\text { - satellites data allow to monitor } \\
\text { topographical changes and to estimate } \\
\text { crop yields; }\end{array}$ \\
\hline \multicolumn{3}{|c|}{ Good Health and Wellbeing } \\
\hline $\begin{array}{c}\text { - diseases propagation } \\
\text { (in order to ending or } \\
\text { limit epidemics and } \\
\text { communicable } \\
\text { diseases); } \\
\text { - reduction of deaths } \\
\text { and injuries caused by } \\
\text { road traffic accidents; }\end{array}$ & $\begin{array}{c}\text { - mobile phone } \\
\text { data; } \\
\text { - social media data; } \\
\text { - medical records; } \\
\text { - search engine } \\
\text { query data; } \\
\text { - sensor data; } \\
\text { - satellites data; }\end{array}$ & $\begin{array}{l}\text {-analyzing of mobile phone user's } \\
\text { mobility and mining the social media } \\
\text { contents allow to predict diseases } \\
\text { propagation; } \\
\text { - supplementary using the medical } \\
\text { records and search engine query data it } \\
\text { is possible to establish the seasonal } \\
\text { trends of diseases; } \\
\text { - data provided by sensors, especially } \\
\text { from various wearables, allow to } \\
\text { monitor the individuals and collective }\end{array}$ \\
\hline
\end{tabular}




\begin{tabular}{|c|c|c|}
\hline & & $\begin{array}{l}\text { health; } \\
\text { - models build from historical data } \\
\text { related to weather, geotagged crash data } \\
\text { and data about different events could } \\
\text { identify the dangerous areas; }\end{array}$ \\
\hline \multicolumn{3}{|c|}{ Quality Education } \\
\hline $\begin{array}{l}\text { - the illiteracy } \\
\text { prediction } \\
\text { - school dropout } \\
\text { prediction; } \\
\text { - trends in education; }\end{array}$ & $\begin{array}{c}\text { - mobile phone } \\
\text { data; } \\
\text { - social media data } \\
\text {-structured and } \\
\text { unstructured data } \\
\text { from surveys or } \\
\text { educational } \\
\text { databases; }\end{array}$ & $\begin{array}{l}\text { - the analysis of mobile phones records } \\
\text { allows to obtain indicators reflecting the } \\
\text { socioeconomic level, that is strong } \\
\text { related with education quality; } \\
\text {-by mining social media content in } \\
\text { various areas it is possible to find } \\
\text { predictors of illiteracy; } \\
\text { - data collected from learning } \\
\text { management systems or from massive } \\
\text { open online courses allow to build } \\
\text { models of engagement or effectiveness } \\
\text { of learning; }\end{array}$ \\
\hline \multicolumn{3}{|c|}{ 5. Gender equality } \\
\hline $\begin{array}{l}\text { - gender inequality } \\
\text { reduction; } \\
\text { - empower women and } \\
\text { girls; } \\
\text { - gender prediction; }\end{array}$ & $\begin{array}{c}\text { - social media data } \\
\text { - mobile phone } \\
\text { data; } \\
\text { - medical records; } \\
\text {-jobs requests } \\
\text { records; } \\
\text { - mobile phones } \\
\text { calls records }\end{array}$ & $\begin{array}{l}\text { - models built on mobile phone data } \\
\text { could predict the user's gender; }\end{array}$ \\
\hline \multicolumn{3}{|c|}{ 6. Clean Water and Sanitation } \\
\hline $\begin{array}{l}\text { - detecting changes in } \\
\text { water-related } \\
\text { ecosystems; } \\
\text { - tracking the water } \\
\text { quality; }\end{array}$ & $\begin{array}{c}\text { - satellites data; } \\
\text { - sensor networks } \\
\text { data; } \\
\text { - smart metering; }\end{array}$ & $\begin{array}{c}\text { - based on satellite data analysis it is } \\
\text { possible to detect the dynamic of water } \\
\text { surfaces and to predict their future } \\
\text { evolution; } \\
\text { - water quality can be assessed starting } \\
\text { from data collected from various sensor } \\
\text { networks; }\end{array}$ \\
\hline \multicolumn{3}{|c|}{ 7. Affordable and Clean Energy } \\
\hline $\begin{array}{l}\text { - access to electricity } \\
\text { - electricity }\end{array}$ & $\begin{array}{l}\text { - satellites data; } \\
\text { - smart metering }\end{array}$ & $\begin{array}{l}\text { - analyzing data collected from } \\
\text { generators and transformers, obtained by }\end{array}$ \\
\hline
\end{tabular}




\begin{tabular}{|c|c|c|}
\hline consumption & & $\begin{array}{l}\text { smart metering, combined with data } \\
\text { provided by satellites it is possible to } \\
\text { estimate the size of population without } \\
\text { access to electricity, or to estimate the } \\
\text { trends in energy usage }\end{array}$ \\
\hline \multicolumn{3}{|l|}{8.} \\
\hline $\begin{array}{l}\text { - GDP level } \\
\text { - unemployment rate } \\
\text { - the scale of tourism }\end{array}$ & $\begin{array}{c}\text { - mobile phones } \\
\text { data; } \\
\text {-search engine } \\
\text { query data; } \\
\text { - postal data; } \\
\text {-satellites data; } \\
\text {-web scraped data; }\end{array}$ & $\begin{array}{l}\text { - daily data collected from online } \\
\text { retailers allows to build a price model } \\
\text { that can contribute to monitor the } \\
\text { economic growth; } \\
\text { - the nighttime luminosity detected from } \\
\text { satellite data is an indicator for the } \\
\text { economic development; } \\
\text { - mining the social media content } \\
\text { combined with other data types } \\
\text { concerning the economic growth } \\
\text { generate models to predict the } \\
\text { unemployment rate; } \\
\text { - data from call activities on roaming } \\
\text { may be used as a basis for scale of } \\
\text { tourism assessing; }\end{array}$ \\
\hline \multicolumn{3}{|l|}{9.} \\
\hline $\begin{array}{l}\text { - investments in } \\
\text { research and } \\
\text { development } \\
\text { - monitoring of } \\
\text { greenhouse gas } \\
\text { emissions } \\
\text { - transport planning }\end{array}$ & $\begin{array}{l}\text { - mobile phone } \\
\text { data; } \\
\text { - satellites data; } \\
\text { - sensor data; }\end{array}$ & $\begin{array}{l}\text { - data from mobile phone calls, Google } \\
\text { traffic or satellite data allow to build } \\
\text { traffic models that can be used to predict } \\
\text { future changes in traffic; }\end{array}$ \\
\hline \multicolumn{3}{|c|}{ 10. Reduced Inequalities } \\
\hline $\begin{array}{c}\text { - assessment of socio- } \\
\text { economic status and } \\
\text { wellbeing }\end{array}$ & $\begin{array}{l}\text { - mobile phone } \\
\text { data; } \\
\text { - social networks } \\
\text { data; }\end{array}$ & $\begin{array}{l}\text { - the mobile services expenses pattern is } \\
\text { an indicator of the standard of living; }\end{array}$ \\
\hline \multicolumn{3}{|r|}{ 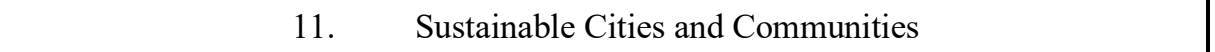 } \\
\hline $\begin{array}{l}\text { - assessing urban } \\
\text { poverty } \\
\text { - mapping poverty }\end{array}$ & $\begin{array}{l}\text { - mobile phones } \\
\text { data; } \\
\text {-satellites data; }\end{array}$ & $\begin{array}{l}\text { - poverty can be related to energy } \\
\text { consumption, so, many data types } \\
\text { provided by satellites can be used to }\end{array}$ \\
\hline
\end{tabular}




\begin{tabular}{|c|c|c|}
\hline $\begin{array}{l}\text { - transport planning } \\
\text { - land use } \\
\text { - disaster response }\end{array}$ & $\begin{array}{l}\text {-search engine } \\
\text { query data; }\end{array}$ & $\begin{array}{c}\text { map the poverty; } \\
\text { - the analysis of telephone calls records } \\
\text { details allows the identification of } \\
\text { people mobility after disasters; }\end{array}$ \\
\hline \multicolumn{3}{|c|}{ Responsible Consumption and Production } \\
\hline $\begin{array}{l}\text { - production } \\
\text { estimation } \\
\text { - consumption } \\
\text { prediction and } \\
\text { reducing food waste }\end{array}$ & $\begin{array}{l}\text { - mobile phones } \\
\text { data; } \\
\text {-satellites data; } \\
\text {-search engine } \\
\text { query data; } \\
\text { - smart metering }\end{array}$ & $\begin{array}{l}\text { - tracking the food-related posts on } \\
\text { social media could reveal, in an early } \\
\text { stage, food inflation; } \\
\text { - satellites data allow to monitor } \\
\text { topographical changes and to estimate } \\
\text { crop yields; }\end{array}$ \\
\hline \multicolumn{3}{|c|}{ 13. Climate Action } \\
\hline $\begin{array}{l}\text { - changes in water- } \\
\text { related ecosystem; } \\
\text { - drought monitoring; } \\
\text { - disaster response; }\end{array}$ & $\begin{array}{l}\text { - mobile phone } \\
\text { data; } \\
\text { - satellite data; } \\
\text { - sensor networks } \\
\text { data; }\end{array}$ & $\begin{array}{c}\text { - based on satellite data analysis it is } \\
\text { possible to detect the dynamic of water } \\
\text { surfaces and to predict their future } \\
\text { evolution; } \\
\text { - the drought detection and } \\
\text { quantification is possible by analyzing } \\
\text { data provided by meteorological } \\
\text { satellites; } \\
\text { - the analysis of telephone calls records } \\
\text { details allows the identification of } \\
\text { people mobility after disasters; }\end{array}$ \\
\hline \multicolumn{3}{|c|}{ 14. Life Below Water } \\
\hline $\begin{array}{l}\text { - identification of } \\
\text { illegal fishing } \\
\text { - identification of the } \\
\text { penetration of the } \\
\text { vessels in the } \\
\text { protected spaces }\end{array}$ & - satellite data; & $\begin{array}{l}\text { - data from satellites can help to monitor } \\
\text { water pollution levels; }\end{array}$ \\
\hline \multicolumn{3}{|c|}{ 15. Life on Land } \\
\hline $\begin{array}{l}\text { - identification of } \\
\text { deforestation } \\
\text { - combating } \\
\text { desertification } \\
\text { - protection of rare } \\
\text { species }\end{array}$ & $\begin{array}{l}\text { - satellite data; } \\
\text { - sensors data; } \\
\text {-search engine } \\
\text { query data; }\end{array}$ & $\begin{array}{l}\text { - combining data from satellites with } \\
\text { meteorological data and data collected in } \\
\text { various databases it is possible to map } \\
\text { the forests and to track and predict the } \\
\text { deforestation; }\end{array}$ \\
\hline
\end{tabular}




\begin{tabular}{|c|c|c|}
\hline \multicolumn{3}{|r|}{ g Institutions } \\
\hline $\begin{array}{l}\text { - prediction of } \\
\text { criminal phenomena } \\
\text { - citizens' perception } \\
\text { of violence } \\
\text { - tracking the } \\
\text { efficiency of justice } \\
\text { systems }\end{array}$ & $\begin{array}{c}\text { - mobile phone } \\
\text { data; } \\
\text { - social media data }\end{array}$ & $\begin{array}{c}\text { - social media data can help to build } \\
\text { crime prediction models trough the } \\
\text { linguistic analysis combined with topic } \\
\text { modelling; } \\
\text {-social media data is a source for } \\
\text { sentiment analysis concerning the } \\
\text { efficiency of justice systems; }\end{array}$ \\
\hline
\end{tabular}

Big Data by the data sources, the modes of analysis and the purpose of using the obtained results.

Specifically, according to the Global Pulse initiative, the corresponding Big Data sources for development have several common features, namely: the data are generated digitally and can be easily manipulated by the computing systems, they are produced in daily activities or through the interaction with digital services, they are collected automatically, they allow temporal or geographical tracking and are analyzed continuously and in real time (Big Data for Development, 2013). Table 2 presents a summary of the relationships between Big Data sources and their applications that are useful for achieving the sustainable development goals.

Through proper exploration and analysis, Big Data allows for a better understanding of human behavior and provides decision makers with support for healthy global development. Experts believe that the information obtained from Big Data analyzes is useful: warnings

- to respond quickly to the needs of the population as a result of early

triggered by detecting anomalies that may indicate various types of crises;

- to raise in real-time the awareness concerning potential issues and to develop targeted programs and policies for solving them;

- to obtain real-time feedback about the impact generated by the implemented programs and policies in order to make the necessary adjustments.

The core of these analyzes consists of algorithms that detect patterns in data, trends and correlations for various periods of time and can generate valuable information by linking data from different sources. 
3.2. Big Data for Development projects - some worldwide examples

Last years, a lot of studies have been carried out and numerous projects aiming to assess the effectiveness of Big Data analyzes for development have been implemented. For example, in Frias-Martinez \& Virseda (2012) and FriasMartinez, Virseda-Jerez \& Frias-Martinez, E. (2012), Frias-Martinez et. al. studied the relationship between socio-economic status, physical mobility and data regarding the use of mobile phones.

In Berhan, Tadesse, Atnafu \& Hill (2011), Berhan et. al. analyzed data collected from satellites to monitor drought conditions and the extent of this phenomenon, and in Kogan, Adamenko \& Kulbida (2011), Kogen et. al. used data from satellites to develop vegetation health indices for early assessment of crop yield.

Top companies such as Nike, Ikea or Hitachi have developed big data systems to understand the impact of their activities along the value chain in which they operate Big data and open data as sustainability tools (2014). In 2014 Cisco signed a partnership agreement with three local administrations in Denmark, with the objective of developing tomorrow's digital infrastructure Internet of Everything. This agreement includes technical solutions aiming to improve the services for citizens. In July 2014, the city of Beijing signed a 10year agreement with IBM - Green Horizon- which uses big data-based tools to solve the city's smog problem. Also in 2014 Google announced its intention to use Skybox satellites to update and increase the accuracy of Google Maps. This makes possible to estimate the dynamics of natural resource reserves almost in real time.

More recently, in 2016, Jean et al. (Jean, Burke, Xie, Davis, Lobell \& Ermon (2016), applied new achievements in the field of machine learning to measure regional poverty in Africa starting from the analysis of day and night images taken from satellites.

\subsection{Big Data for Development in Romania}

Romania adopted its first sustainable development strategy in 1999. This strategy aims to improve progressively and maintain the well-being of the population in correlation with the need for the rational use of natural resources and the ecosystems conservation. With the accession to the European Union, in 2007, the national priorities were adjusted through the National Sustainable Development Strategy. As a member of the United Nations and European Union, Romania joined the Agenda 2030 and established the national 
framework for the implementation of the 17 sustainable development goals Strategia Națională pentru Dezvoltarea Durabilă a României 2030).

The National Strategy on Digital Agenda for Romania 2020 (2015) highlights the role of information and communications technology (ITC) in supporting the development of the economy and society, and according to the National Strategy for Research and Innovation 2014-2020 (2014) one of the essential dimensions of modern IT solutions is data.

As a result, many companies intend to develop Big Data projects in Romania, aiming to support essential processes for sustainable development, such as developing smart cities, increasing productivity, improving resource consumption or developing quality education. There are identified and partially developed systems that will be sources for Big Data for development, but the need for a specific infrastructure for Big Data analysis and the lack of adequate investments is still a brake on the implementation of major projects.

\section{Conclusion:}

Big Data allows the analysis of large, variate and dynamic data sets helping to make informed strategic decisions. Big Data for Development refers to transforming complex data into actionable information, with the purpose of supporting sustainable development.

Despite the many challenges that Big Data for Development must face (e.g. privacy issues, access, infrastructure), understanding and using the models from analyzing data that human communities produce can be considered true catalysts for sustainable development.

\section{References:}

1. Berhan, G., Tadesse, T., Atnafu, S. \& Hill, S. (2011), Drought Monitoring in FoodInsecure Areas of Ethiopia by Using Satellite Technologies, Experiences of Climate Change Adaptation in Africa (pp. 183-200, Springer, Berlin, Heidelberg.

2. Danubianu Mirela, Barila Adina (2014), Big Data vs Data Mining for Social Media Analytics, Proc of International Conference on Social Media in Academia Research and Teaching - SMART 2014.

3. Frias-Martinez, V., Virseda-Jerez, J., \& Frias-Martinez, E. (2012), On the relation between socio-economic status and physical mobility, Information Technology for Development, 18 (2), 91-106.

4. Frias-Martinez, V., \& Virseda, J. (2012), On the relationship between socio-economic 
factors and cell phone usage, Proceedings of the fifth international conference on information and communication technologies and development, March, 2012, (pp. 76-84). ACM.

5. Jean, N., Burke, M., Xie, M., Davis, W. M., Lobell, D. B., \& Ermon, S. (2016), Combining satellite imagery and machine learning to predict poverty. Science, 353 (6301), 790-794.

6. Kogan, F., Adamenko, T., \& Kulbida, M. (2011), Satellite-based crop production monitoring in Ukraine and regional food security, Use of Satellite and In-Situ Data to Improve Sustainability (pp. 99-104), Springer, Netherlands.

7. Paraschiv, A.M., Danubianu, Mirela, (2019),. BIG DATA - Present Opportunities and Challenges. BRAIN. Broad Research in Artificial Intelligence and Neuroscience, 10, pp.15-21.

8.(1987), Brundtland Report, https://www.are.admin.ch/are/en/home/sustainabledevelopment/international-cooperation/2030agenda/un- -milestones-insustainable-development/1987--brundtland-report.html

9. (2012), Global Pulse - Big Data for Development: Challenges \& Opportunities, May, 2012.

10. (2012), Global Pulse, Big Data for development: A Primer, 2013

11. (2014), Big data and open data as sustainability tools, A working paper prepared by the Economic Commission for Latin America and the Caribbean.

12. (2014), SN-CDI 2020. Strategia Naţională de Cercetare-Inovare 2014-2020 versiunea tehnică., Ministerul Educaţiei şi Cercetării Ştiinţifice, februarie 2014. http://www.cdi2020.ro/wpcontent/uploads/2014/02/STRATEGIA Versiuneatehnica Februarie-2014.pdf

13. (2015), SN-ADR: Strategia Naţională privind Agenda Digitală pentru România 2020, Ministerul pentru Societatea Informaţională, București. https://www.google.ro/url?sa=t\&rct=

$\mathrm{j} \& \mathrm{q}=\&$ esrc $=$ s\&source $=$ web $\& \mathrm{~cd}=1 \& \mathrm{ved}=0$ ahUKEwitjO2SrqHJAhVFOxoKHXER BcQQFggcMAA\&url=http\%3A\%2F\%2Fwww.mcsi.ro\%2FCMSPages\%2FGetFil e.aspx\%3Fnodeguid\%3D0617c1d7-182f-44c0-a9784d8653e2c31d\&usg=AFQjCNGvMiD0UUKjm5Jr4Wgj0Hp NUb XUXQ

14. (2015), Transforming our world: the 2030 Agenda for Sustainable Development, United Nations.

15. (2016), The Classification for Global SDG Indicators, PDF. from http://docplayer. net/27317561-Tier-classification-forglobal-sdg-indicators-21-december-2016.html

16. (2018), Raportul Eurostat - Dezvoltarea durabilă în Uniunea Europeană - raport de monitorizare privind progresele înregistrate $\hat{\imath}$ direcția atingerii obiectivelor de dezvoltare durabilă (ODD) în contextul UE - ediția 2018.

17. Strategia Națională pentru Dezvoltarea Durabilă a României 2030, ISBN 978-606748-261-4.

(C) 2020 by the authors. Licensee UAIC, Iasi, Romania. This article is an open access article distributed under the terms and conditions of the Creative Commons Attribution (CC BY-NC-ND) license (https:// creativecommons.org/licenses/by-nc-nd/4.0). 